\title{
Feral honey bees in pine forest landscapes of east Texas
}

\author{
Robert N. Coulson ${ }^{\mathrm{a}, \mathrm{b}, *}$, M. Alice Pinto ${ }^{\mathrm{c}}$, Maria D. Tchakerian ${ }^{\mathrm{a}}$, \\ Kristen A. Baum ${ }^{\text {d }}$, William L. Rubink ${ }^{\mathrm{e}, 1}$, J. Spencer Johnston ${ }^{\text {a }}$ \\ ${ }^{a}$ Knowledge Engineering Laboratory, Department of Entomology, Texas A\&M University, College Station, TX 77843-2475, USA \\ ${ }^{\mathrm{b}}$ Knowledge Engineering Laboratory, Department of Forest Science, Texas A\&M University, College Station, TX 77843-2475, USA \\ ${ }^{\mathrm{c}}$ Departamento Florestal, Escola Superior Agrária, Instituto Politécnico de Bragança, Campus de Santa Apolónia, \\ Apartado 172, 5301-854 Bragança, Portugal \\ ${ }^{\mathrm{d}}$ Department of Zoology, 430 Life Sciences West, Oklahoma State University, Stillwater, OK 74078, USA \\ ${ }^{\mathrm{e}}$ Beneficial Insects Research Unit, Honey Bee Group, USDA-ARS, Weslaco, TX 78596, USA
}

Received 6 February 2005; received in revised form 3 May 2005; accepted 4 May 2005

\begin{abstract}
In 1990 the Africanized honey bee, a descendent of Apis mellifera scutellata, was identified in south Texas [Hunter, L.A., Jackman, J.A., Sugden, E.A., 1992. Detection records of Africanized honey bees in Texas during 1990, 1991 and 1992. Southwestern Entomol. 18, 79-89]. The potential impact of this immigrant on feral and managed colonies was the subject of considerable speculation. The goal of this study was to investigate the diversity of feral honey bee races in pine forest landscapes of east Texas, subsequent to immigration of $A$. $m$. scutellata. The specific objectives were (i) to assess the immigration of $A$. $m$. scutellata into east Texas pine forest landscapes and (ii) to evaluate the suitability of the pine forest landscape to feral honey bees. This mesoscale landscape study was conducted on the Sam Houston National Forest in east Texas. Swarm traps and aerial pitfall traps were used to monitor feral honey bees. Spatial databases were used to evaluate suitability of the pine forest landscape for honey bees.

Scoring mitochondrial DNA type (mitotypes), we found representatives of A. mellifera scutellata, eastern European, western European, and A. mellifera lamarckii races in pine forest landscapes of east Texas. The conclusions that follow from this aspect of the investigation are (i) honey bees are a ubiquitous component of the pine forest landscape in east Texas, (ii) mitotype diversity persists subsequent to the immigration of A. m. scutellata, and (iii) A. m. scutellata is an added element of the mitotype diversity in the landscape.

To evaluate quantitatively the suitability of the pine forest to feral honey bees, we used a spatial database for the study area and FRAGSTATS. The landscape structure in 1256 ha units surrounding six swarms of honey bees captured in the swarm traps was examined. The metrics used to characterize the kind, number, size, shape, and configuration of elements forming the landscape, defined a heterogeneous environment for honey bees that included sufficient food and habitat resources needed for survival, growth, and reproduction. The conclusions that follow from this aspect of the investigation are (1) although classified as a pine forest, management practices and other human activities have altered the landscape and thereby created food and habitat resources suitable for honey bees, (2) the forestry practices associated specifically with road corridor maintenance, stream side corridor protection, RCW management, and Wilderness Area management introduce structural heterogeneity to the forest
\end{abstract}

\footnotetext{
* Corresponding author. Tel.: +1 979845 9725; fax: +1 9798624820.

E-mail address: r-coulson@tamu.edu (R.N. Coulson).

${ }^{1}$ Present address: P.O. Box 2686, Edinburgh, TX 78540, USA.
} 
landscape which enriches the diversity and abundance of early successional flowering plants and provides cavity sites needed by honey bees, (3) ranching, farming, and urbanization within the study area also create these conditions, and (4) based on inferences from melissopalynology, honey bees provide pollination services for a broad representation of native and introduced flowering plant species of the pineywoods ecoregion.

(C) 2005 Elsevier B.V. All rights reserved.

Keywords: Feral honey bees; Forest landscape structure; Mitotype diversity; Apis mellifera scutellata

\section{Introduction}

The pineywoods ecoregion of east Texas is dominated by commercially important species of southern yellow pine. Shortleaf (Pinus echinata Mill.) and loblolly pine (P. taeda L.) are common. Longleaf (P. palustris Mill.) and slash pine (P. elliotti Engel.) are also present. The specific composition of plant communities varies as a function of elevation, soil type, and moisture. The plant communities include many native and introduced species of flowering trees, shrubs, and herbs (Ricketts, 1999). The physical landscape is highly fragmented, dissected, and perforated as a consequence of human activities associated with forestry, agriculture, ranching, and urbanization.

Settlers brought honey bees to east Texas and through time beekeepers introduced races from eastern Europe (A. m. caucasica, A. m. carnica, and A. m. ligustica), western Europe (A. m. mellifera, A. m. iberica), and north Africa (A. m. lamarckii) (Sheppard, 1989a,b; Schiff and Sheppard, 1993; Schiff et al., 1994; Pinto et al., 2004). The feral populations occurring in the landscapes of the ecoregion today are a legacy of these introductions.

A new race of honey bee was introduced into the New World when A. m. scutellata was imported into Brazil from South Africa in 1956 (Kerr, 1967). This sub-Saharan tropical sub-species was accidentally released in 1957 and descendents have dispersed and established feral populations throughout most of South America, Central America, and the southwestern US. In 1990 A. m. scutellata was identified in south Texas (Hunter et al., 1993). Several studies found these honey bees to be hybrids of the African, $A$. m. scutellata, and European races (Lobo et al., 1989; Pinto et al., 2004; Rinderer et al., 1991; Sheppard et al., 1991; Clarke et al., 2002). The hybrids are commonly referred to as Africanized honey bees.

The immigration of Africanized honey bees into Texas was a much anticipated event and their potential impact on feral populations and managed colonies was a subject of considerable speculation. The studies by Schiff and Sheppard (1993) and Schiff et al. (1994) were conducted, in part, to identify the background races of feral honey bees present in the southern US before the immigration of Africanized honey bees occurred. The races documented in the studies could be used as the reference state for evaluating the impact of Africanized bees on existing feral populations. Although, domesticated honey bees are among the most thoroughly studied organisms, the impact of feral populations on natural landscapes, particularly forests, is poorly understood and perhaps greatly undervalued (Buchmann and Nabhan, 1996). Accordingly, the goal of this study was to investigate the diversity of feral honey bee races in pine forest landscapes of east Texas, subsequent to immigration of A. m. scutellata. The specific objectives were (i) to assess the immigration of A. m. scutellata into east Texas pine forest landscapes and (ii) to evaluate the suitability of the pine forest landscape to feral honey bees. Pinto et al. (2004) and Baum (2003) have examined in detail the spatial and temporal genetics and ecology of feral Africanized honey bees in a coastal prairie landscape of south Texas. However, little is known about feral honey bees in pine forest landscapes.

\section{Methods and materials}

\subsection{Study site}

This study was conducted on the Sam Houston National Forest (SHNF) in Montgomery Co., Texas. The SHNF is managed by the USDA Forest Service, National Forest System, for multiple purposes. At the mesoscale (100-1,000,000 ha), i.e., the scale of this study, the landscape structure consisted of a loblolly/ shortleaf pine matrix, several distinct patch types that result from different land uses and management 


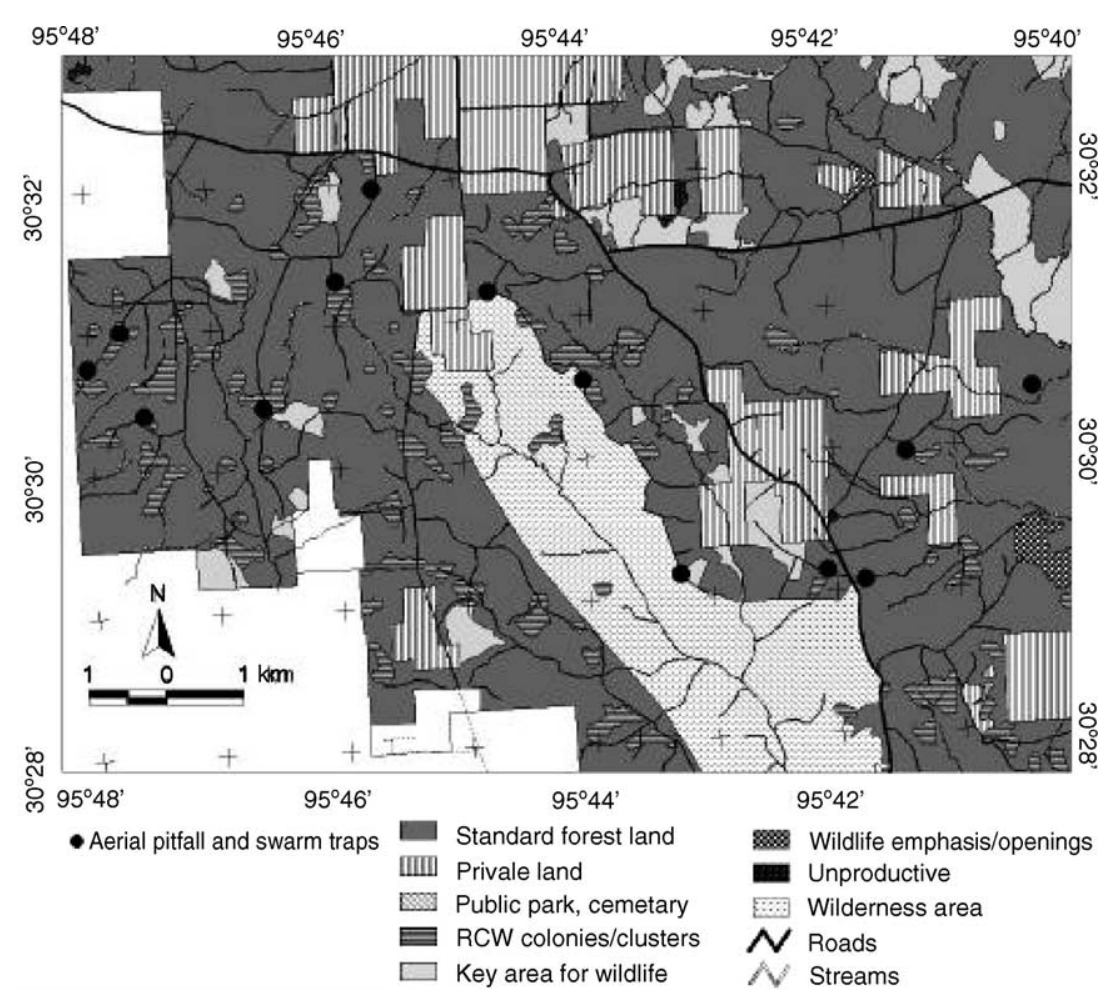

Fig. 1. The study site on the Sam Houston National Forest in east Texas. The structure of the mesoscale landscape consisted of a loblolly/shortleaf pine matrix, several distinct patch types that result from different land uses and management practices, and an extensive and maintained road and stream corridor network. The locations of swarm traps and scout traps used to monitor feral honey bees are delineated by circles on the map.

practices, and an extensive and maintained road and stream corridor network (Fig. 1). Several features of the landscape structure of the study site are noteworthy. Red-cockaded Woodpecker (RCW, Picoides borealis (Vieillot)) management areas were a prominent patch type in the study site (Fig. 1). Another important feature of the study site was the Little Lake Creek Wilderness Area. This 1796 ha tract was set aside from normal forest management in 1984. The study site also contained private property. In addition to residences (with associated outbuildings), the private holdings were used primarily for cattle and horse ranching.

\subsection{Monitoring feral honey bees}

Two methods were used to monitor feral honey bee activity on the SHNF: swarm traps and aerial pitfall traps. Each trap provided different information about the feral honey bees in the forest landscape. The swarm traps were intended to capture reproductive swarms of honey bees (a queen and workers) in the process of establishing a colony in a new location. The aerial pitfall traps were intended to capture honey bees foraging for resources (e.g., nectar, pollen, water, propolis) or scouting for cavity sites.

The swarm trap used in the study was described by Schmidt and Thoenes (1987) and Schmidt et al. (1989). The trap has been found suitable for capturing swarms of both European and Africanized honey bees (Schmidt and Hurley, 1995). Each trap was baited with a 1:1 citral:geraniol mixture and a small quantity of beeswax which served as honey bee attractants. The traps were attached to trees at ca. $2 \mathrm{~m}$ above the ground using a rope tether (Fig. 2b). In all, 13 traps were deployed on March 6 and 7, 2002 at different locations along and adjacent to forest road corridors within the study site (Fig. 1). The traps were monitored on ca. a weekly schedule from deployment through November 2002. Once the swarms were 

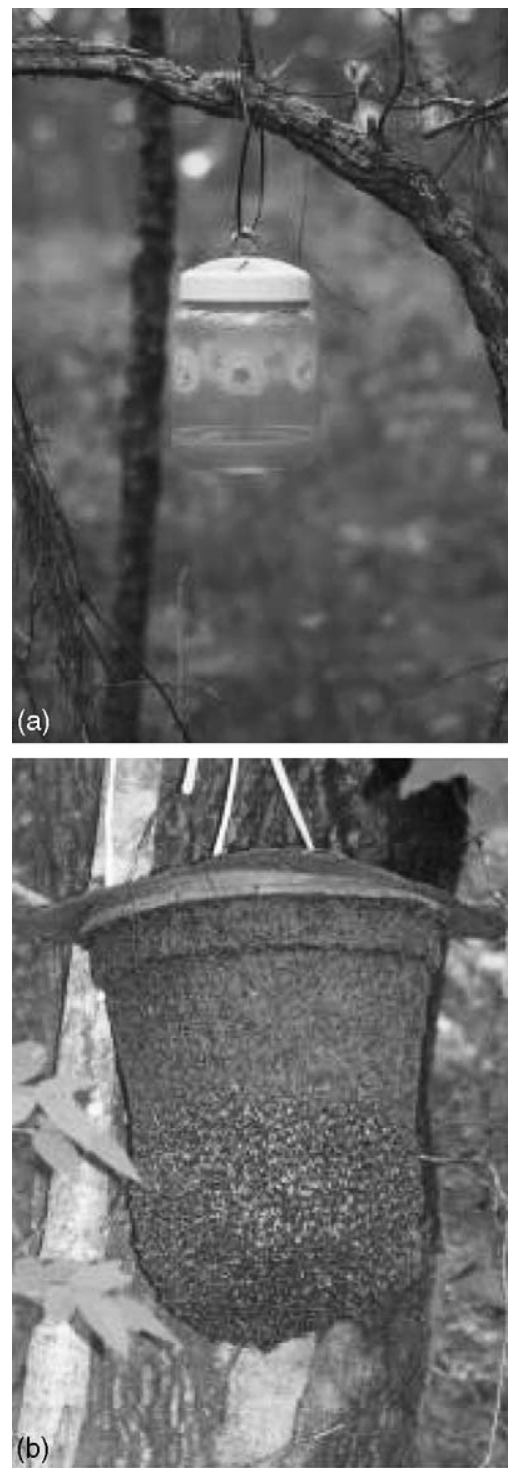

Fig. 2. (a) Aerial pitfall trap used to capture honey bees foraging for food and water resources and scouring for cavity sites. Detailed specifications for the pitfall traps are described by Baum (2003). (b) Swarm trap used to capture swarms of honey bees in the process of establishing a colony in a new location. Detailed specifications for the swarm traps are described by Schmidt and Thoenes (1987) and Schmidt et al. (1989).

established a sample of honey bees was collected from each trap using an insect net. The specimens were placed in $95 \%$ ethanol. Geographic coordinates of the traps were recorded using an GeoExplorer $\mathrm{XT}^{\mathrm{TM}}$ GPS/Datalogger.
The design of the aerial pitfall trap used in this study was described in detail by Rubink et al. (2003) and Baum (2003). The traps were baited with a 1:1 citral:geraniol mixture and honey. Propylene glycol was placed in each trap and served to preserve captured arthropods (Fig. 2a). Rubink et al. (2003) found that DNA from honey bees collected in this manner was suitable for analysis. The traps were attached to trees at ca. $2 \mathrm{~m}$ from the ground. Thirteen traps were deployed on March 12, 2002 at the same general locations as the swarm traps (Fig. 2). Geographic coordinates of the aerial pitfall traps were nominally the same as the swarm traps. The traps were monitored on ca. a weekly schedule from deployment through November 2002. Captured honey bees were removed from the traps and preserved in 95\% ethanol. Aerial pitfall traps were removed from sites when and where swarm traps became occupied.

\subsection{Identification of honey bee races}

The races of honey bees captured in the swarm traps and aerial pitfall traps were identified by scoring mitochondrial DNA type (mitotype). Because a mitotype represents inheritance from mother to offspring in an uninterrupted maternal lineage, and lacking information on admixture that may or may not have occurred to the nuclear DNA, we equate mtDNA to race; and the terms race and mitotype are used synonymously. Simple polymerase chain reaction (PCR) assays that allow identification of maternal races have been developed and described in detail by Pinto et al. (2003). In preparation for the PCR analyses, total DNA was extracted from tissues in the thorax of the honey bee workers using a QIAamp ${ }^{\circledR}$ DNA Mini Kit (Qiagen Inc., Valencia, CA) according to the instructions of the manufacturer. Given the maternal inheritance and the reproductive biology of honey bees, a single bee represents the entire colony mitotype. Thus, only one bee per swarm trap was analyzed. Since bees collected in aerial pitfall traps may represent different colonies, all of them were analyzed. Following DNA extraction, cytochrome $b$ (Crozier et al., 1991), large ribosomal subunit (1s rRNA) (Hall and Smith, 1991), and cytochrome oxidase I (COI) (Nielsen et al., 2000) regions of the mitochondrial genome were PCR-amplified and digested with BglII, EcoRI, and HinfI (Promega), 


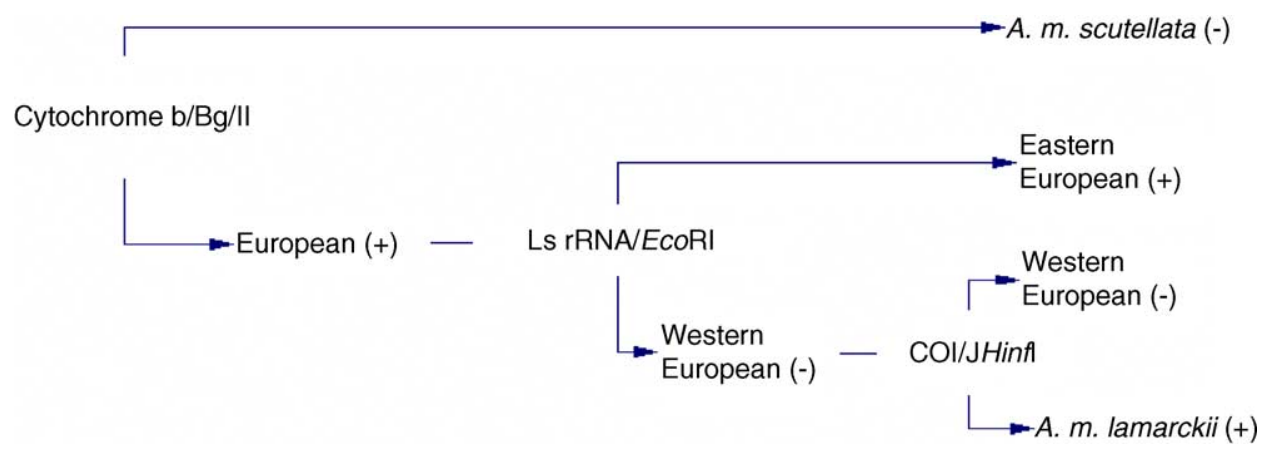

Fig. 3. The methodology used to discriminate among mtDNA types (mitotypes) which permitted the separation of races of honey bees. Colonies determined to carry A. $m$. scutellata mitochondria following BglII digestion of the cytochrome $b$ PCR-amplified fragment (Crozier et al., 1991; Pinto et al., 2003) were not further analyzed. Colonies that exhibited a European mitotype were PCR-amplified for 1s rRNA and digested with EcoRI (Hall and Smith, 1991). Baseline data developed from Old World colonies revealed that EcoRI polymorphism does not discriminate western European mitotypes from A. m. lamarckii (M.A. Pinto, unpublished data). Thus, colonies of western European origin (Hall and Smith, 1991) were further PCR-amplified for COI and digested with HinfI (Nielsen et al., 2000). The "+" sign indicates presence of a restriction site, "_" indicates its absence (flow chart from Pinto et al., 2003).

respectively. The PCR reactions and restriction enzyme digestions were described in detail by Pinto et al. (2003). The honey bee sample mitotypes were scored as shown in Fig. 3. As the focus of this study is on the maternally inherited mtDNA, hereafter the mitotypes will be referred as A. $m$. scutellata, eastern European, western European, and A. m. lamarckii.

\subsection{Landscape analysis}

Examination of the suitability of the pine forest landscape to feral honey bees involved two tasks: (i) development of a spatial database for the study site and (ii) analysis of landscape structure where honey bees occurred. The procedures used to address these tasks are described below.

\subsection{Spatial database}

The spatial database for this study was organized and developed using Arc View ${ }^{\circledR}$ Version 3.2 and Arc/ Info ${ }^{\circledR}$ geographic information systems (GIS) running on a Windows NT 4.0 workstation. Spatial and tabular databases provided by the USDA Forest Service for the SHNF were used to carry out the landscape analysis of the study area. The data for this mesoscale landscape included two types of GIS coverages. The first type was thematic map data on land classification extracted from the Continuous Inventory of Stand
Conditions (CISC) database maintained by the USDA Forest Service. The second type of GIS coverages dealt with data on streams, roads, RCW clusters, and land ownership. The different coverages were combined to define a landscape structure layer with 10 cover types based on land use/land cover characteristics (Table 1). This coverage portrayed the condition of the landscape as it was in 2002 .

\subsection{Data analysis}

The purpose of the analysis was to assess quantitatively the suitability of the forest landscape for use by honey bees. Emphasis in the analysis was focused on the cluster of landscape elements adjacent to occupied swarm traps. Using the coordinates of each swarm trap as the geographic centroid, we delineated a circle with a $2 \mathrm{~km}$ radius (Fig. 6). The landscape structure of each circular area was analyzed using the program FRAGSTATS (McGarigal and Marks, 1995). The structure was quantified using a set of indices developed to measure landscape composition and configuration. Five indices were used: the number of patches, mean patch size, mean patch shape index, patch density, and patch richness (see Table 2 for definitions of each metric). These landscape indices quantify the amount and distribution of each cover type in the landscape and are often interpreted as fragmentation indices (McGarigal et al., 2001). 
Table 1

Cover types used to define landscape structure on the Sam Houston National Forest

\begin{tabular}{|c|c|}
\hline Cover type & Description \\
\hline Standard forest land & $\begin{array}{l}\text { Overstory vegetation dominated by } \\
\text { southern yellow pine. Shortleaf } \\
\text { and loblolly pine are common. } \\
\text { Longleaf and slash are also present }\end{array}$ \\
\hline Private land & Private holdings \\
\hline Public park, cemetery & Public areas \\
\hline RCW colonies/clusters & $\begin{array}{l}\text { Red-cockaded Woodpecker }(\mathrm{RCW}) \\
\text { colonies. Understory vegetation } \\
\text { has been cleared }\end{array}$ \\
\hline $\begin{array}{l}\text { Wildlife } \\
\text { emphasis/openings }\end{array}$ & $\begin{array}{l}\text { Unsuitable land for timber production } \\
\text { assigned for wildlife purposes }\end{array}$ \\
\hline Key area for wildlife & $\begin{array}{l}\text { Suitable land for timber production } \\
\text { assigned for wildlife purposes }\end{array}$ \\
\hline Unproductive & Unsuitable land for timber production \\
\hline Wilderness area & $\begin{array}{l}\text { Areas restricted from normal forest } \\
\text { management practices }\end{array}$ \\
\hline Streams & All perennial streams, rivers, etc. \\
\hline Roads & $\begin{array}{l}\text { All types of roads, including primary, } \\
\text { secondary, and tertiary roads }\end{array}$ \\
\hline
\end{tabular}

\section{Results and discussion}

\subsection{Immigration of A. m. scutellata into east Texas pine forest landscapes}

Data on swarms from Texas were included in the surveys conducted by Schiff and Sheppard (1993) and Schiff et al. (1994) to identify races of honey bees in the southern US. Prior to this investigation, A. m. scutellata had not been reported in Montgomery Co., where this study was conducted. Furthermore, the specific races associated with the pineywoods ecoregion had not been previously identified. The cytochrome $b / B g l I I$ assay (Crozier et al., 1991; Pinto et al., 2003) permitted discrimination of races belonging to the African maternal lineage (A. mellifera scutellata) from the eastern and western European lineages. The 1s rRNA/ EcoRI assay permitted the separation of eastern European maternal lineage (including A. m. caucasica, A. m. carnica, and A. m. ligustica) from western European lineage (including A. m. mellifera and A. m. iberica with mellifera-like mtDNA) (Hall and Smith, 1991). Finally, the COI/HinfI assay identified the colonies maternally descended from A. m. lamarckii (the Egyptian race) (Nielsen et al., 2000). Using this mtDNA approach we found representatives of $A . m$. scutellata, eastern European, western European, and $A$. m. lamarckii races in pine forest landscapes of east Texas. No attempt was made to distinguish among the races occurring within the eastern and western European lineages.

Fig. 4 illustrates the locations where the various races of honey bees (A. m. scutellata, eastern European, western European, and A. m. lamarckii) were found and their relative association within the study site. At various times throughout the course of the investigation, honey bees were captured in each of the 13 aerial pitfall traps. Multiple races were captured in seven of these traps. Swarms colonized seven of the 13 swarm traps: five were A. m. scutellata and two eastern European (Fig. 4). Swarming occurred during the first week in May, 2002 and the traps used by the honey bees were all occupied within a 10 day period.

The relative proportion of honey bee races identified in this study are illustrated in Fig. 5a and b. In the aerial pitfall traps, A. m. scutellata and eastern European races were most prevalent. A. m. lamarckii and western European races were the least abundant races captured. In the swarm traps A. m. scutellata dominated. The eastern European component is common because this group includes the races of honey bee used in contemporary beekeeping in Texas. No commercial

Table 2

Landscape indices used to quantify fragmentation in landscape structure (McGarigal and Marks, 1995)

\begin{tabular}{|c|c|c|}
\hline Landscape index (units) & Abbreviation & Description \\
\hline Number of patches & NP & Number of patches \\
\hline Mean patch size (ha) & MPS & Average size of the patches comprising the landscape or class \\
\hline Mean shape index & MSI & $\begin{array}{l}\text { Averages patch shape complexity for patches comprising the } \\
\text { landscape or class; equals } 1 \text { when all patches are circular and } \\
\text { increases as patches become noncircular }\end{array}$ \\
\hline Patch density (NP/ha) & PD & Number of all patches of the corresponding class per hectare \\
\hline Patch richness & PR & Number of patch cover types present \\
\hline
\end{tabular}




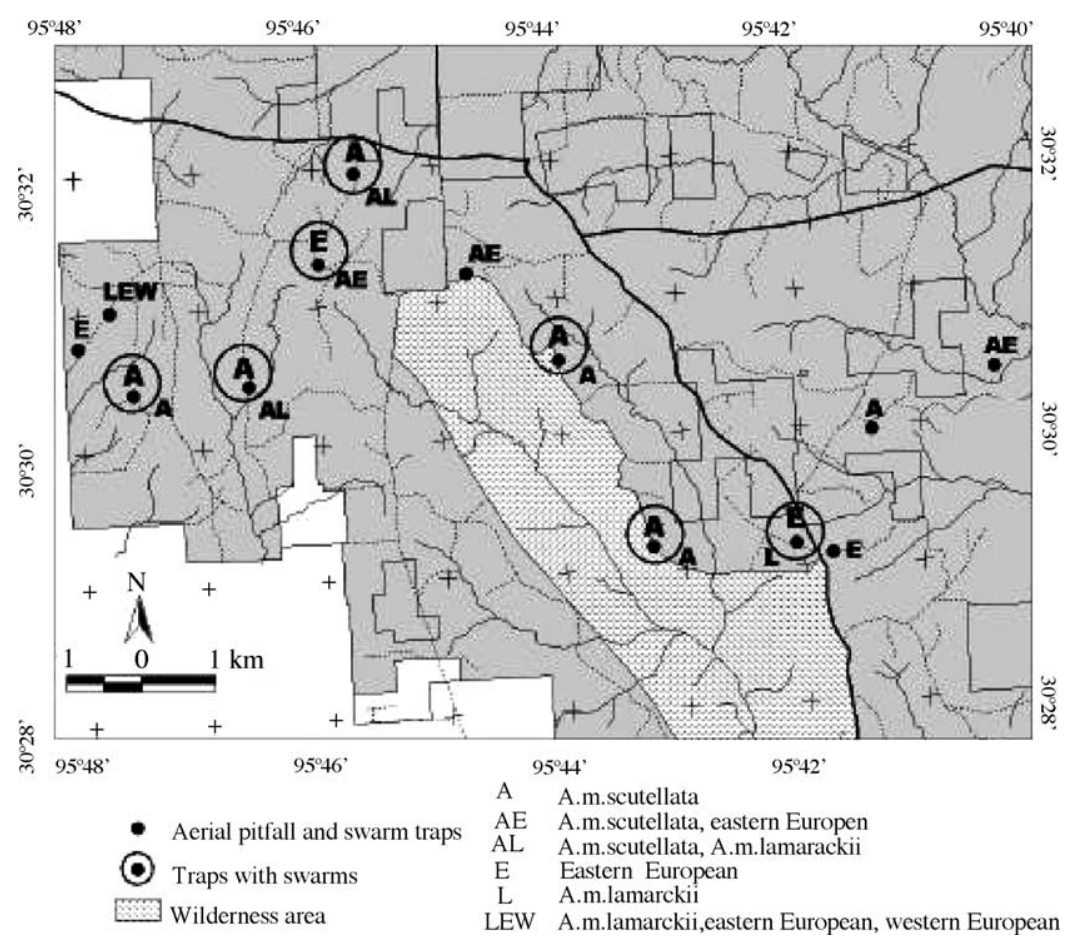

Fig. 4. The locations of aerial pitfall and swarm traps where feral honey bees were collected. The races (mitotypes) of honey bees captured at each site are defined by the symbols on the legend. Abbreviations inside the circle are for honey bees captured at swarm traps. Abbreviations outside the circle represent the honey bee races captured in the aerial pitfall traps. A. m. scutellata, eastern European, western European, and A. $m$. lamarckii races were identified from the pine forest landscape.

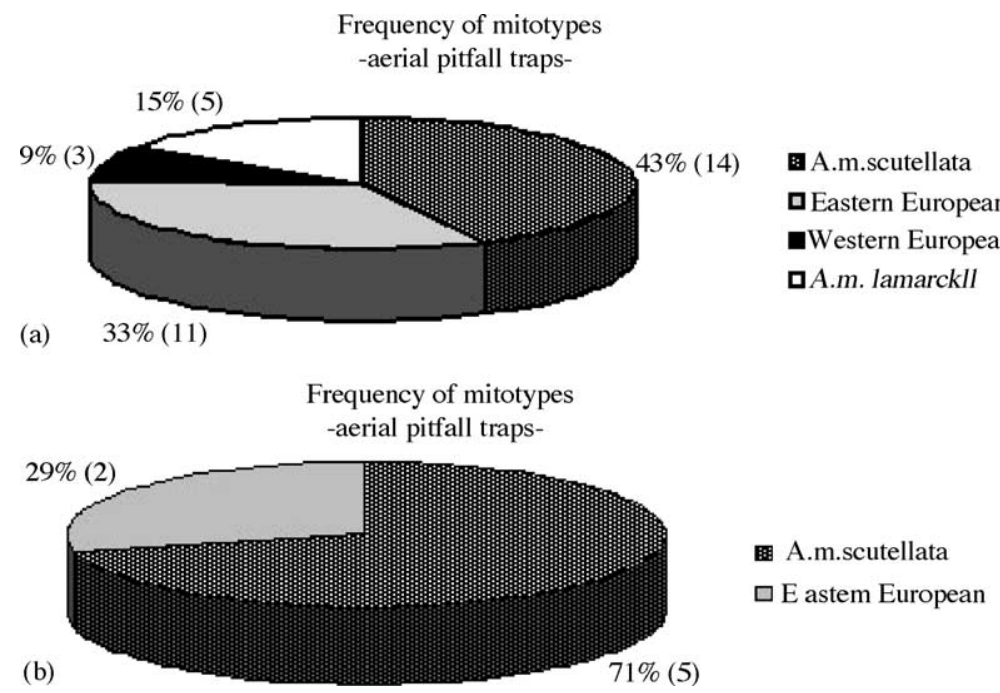

Fig. 5. (a) The relative proportion of honey bee races identified from the aerial pitfall traps. A. m. scutellata and eastern European races were most prevalent. The eastern European component is common because this group includes the races of honey bee used in contemporary beekeeping in Texas. (b) The relative proportion of honey bee races identified from the swarm traps. In the swarm traps A. m. scutellata were the dominate race. 
beekeeping occurred within the study site, but it is possible that some of the residents were hobby beekeepers.

Honey bees are not indigenous to the New World and the present-day European mitotypes and $A . m$. lamarckii (the north African mitotype) were introduced into the Americas at two time intervals: in the early to mid-1600s by English and Spanish colonists and later by bee breeders during the period between 1859 and 1922 (Sheppard, 1989b). The full measure of mitotype diversity that persists today in the pineywoods ecoregion is a remarkable state, as the constituent landscapes have been greatly modified by human activities. When the SHNF was established in 1936 the initial land base had been heavily logged by private owners or was in agricultural production. Since then, several models of forest management have been employed by the Forest Service (e.g., dominant use, multiple use, environmentally sensitive multipleuse, and ecosystem management (Yaffee, 1999)). All have resulted in changes to landscape structure that affected both resources and conditions of the forest environment as perceived by honey bees. As nonindigenous invasive species, honey bees have clearly demonstrated, through persistence of mitotype diversity, remarkable resilience and adaptability to a continuously changing environment.

A. $m$. scutellata is well adapted to a neo tropical environment and it has prospered in areas within this climatic regime where feral European bees could not survive and beekeepers had difficulty in maintaining colonies of the European mitotypes. In contrast to European mitotypes, A. m. scutellata has several behavioral attributes that are beneficial to survival in neo tropical environments: e.g., accentuated defensive behavior, higher rates of brood production, shorter development time, more frequent swarming and absconding, smaller colony size, and perhaps greater tolerance of the parasitic Varroa mite, Varroa destructor (Spicak et al., 1991; Winston, 1991).A. m. scutellata has also been observed to establish colonies in sheltered locations generally unsuitable for European mitotypes, e.g., cavities within the ground [water meter boxes in urban environments], under protected roof overhang of buildings, within fallen trees, etc. Whether these attributes confer competitive advantages to feral populations of $A$. m. scutellata in temperate regions of the US, where European mitotypes prosper, was the subject of considerable speculation among ecologists as well as beekeepers. In the pineywoods ecoregion, which has a mild temperate climate, we found that European mitotype diversity persisted in the presence of immigration of A. m. scutellata. A. m. scutellata became an added element of the mitotype diversity in the landscape, but it did not displace the European mitotypes.

The honey bee mitotype diversity we observed in pineywoods ecoregion mirrors that reported by Pinto et al. (2004) in the adjacent coastal prairie ecoregion of TX. However, the environmental conditions for these two ecoregions are quite different. The coastal prairie provides ideal habitat for honey bees: cavity sites are plentiful in live oak mottes and in the deciduous trees that border stream corridors, high diversity of flowering plant species provides ample nectar and pollen, and water sources are reliable and widespread (Baum, 2003; Baum et al., 2004). In a representative landscape of the coastal prairie ecoregion, Baum (2003) reported a density of 12.5 colonies $/ \mathrm{km}^{2}$, the highest ever observed for feral honey bees. By contrast the pineywoods ecoregion is depauparate of essential resources and in this environment the adaptive attributes of $A$. m. scutellata, which favor colonization of new habitats, could lead to the displacement of European mitotypes. However, we found that in this conifer-dominated forest environment, sparse in honey bee food and habitat resources, all the mitotype diversity that could be present, based on previous introductions, was represented.

The conclusions that follow from this part of the investigation of feral honey bee races are: (i) honey bees are a ubiquitous component of the pine forest landscape in east Texas, (ii) mitotype diversity persists in the presence of immigration of A. m. scutellata, and (iii) A. m. scutellata is an added element of the mitotype diversity in the landscape.

\subsection{Evaluation of the suitability of the pine forest landscape to feral honey bees}

To characterize the suitability of the pine forest landscape to feral honey bees, we examined the landscape structure surrounding the swarms of honey bees captured in the swarm traps (Fig. 6). The rationale for this approach was that nest site recruitment by honey bees prior to swarming is based on evaluation and consensus by the colony. Presumably, 


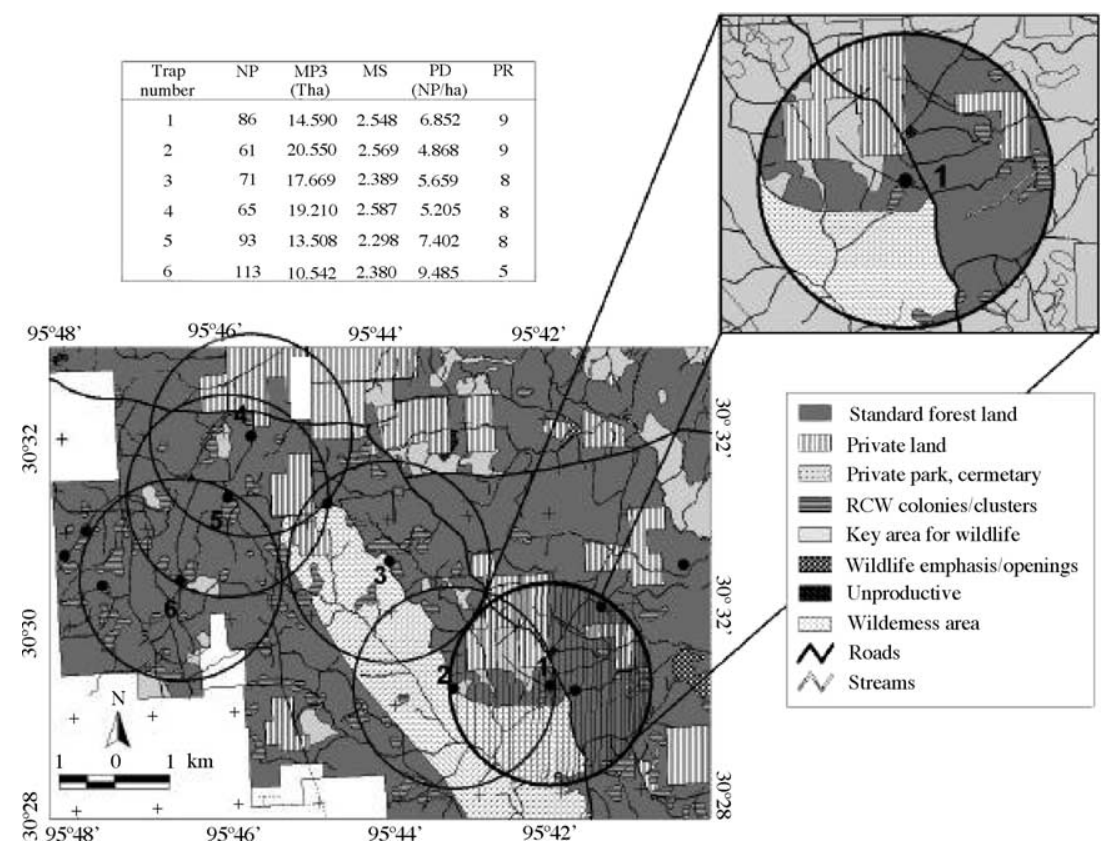

Fig. 6. The study site on the Sam Houston National Forest. The land use types used to classify the landscape are defined in the legend. To evaluate quantitatively the suitability of the pine forest landscape to feral honey bees, the landscape structure surrounding the swarms of honey bees captured in the swarm traps was examined. Using the coordinates of each occupied swarm trap as the geographic centroid, we delineated a circle with a $2 \mathrm{~km}$ radius and evaluated the landscape structure within this 1256 ha unit. The metrics used to characterize the landscape cluster included the kind of patches (PR), number (NP), size (MPS), shape (MSI), and configuration (PD) of elements forming the landscape (McGarigal and Marks, 1995). The results of the analyses are contained in the insert.

a suitable nest site is selected (Camazine et al., 1999; Seeley and Buhrman, 2001). Using the coordinates of each occupied swarm trap as the geographic centroid, we delineated a circle with a $2 \mathrm{~km}$ radius and evaluated the landscape structure within this 1256 ha unit. The rationale for this sample unit was that survival and growth of the colony would be influenced by proximity of needed resources to the nest site, i.e., the resources associated with the cluster of interacting ecosystems (landscape elements) surrounding the colony. This assumption follows from Forman (1995) spatial flow principle (guideline) and the concept of functional heterogeneity of landscapes (Coulson et al., 1999). Studies of foraging behavior of honey bees (Visscher and Seeley, 1982; Schneider, 1989; Schneider and McNally, 1993; Schneider and Hall, 1997; Beekman and Ratnieks, 2000) have identified a variety of factors that influence the process and clearly the distance can be greater than the $2 \mathrm{~km}$ radius of the sample unit. Further, selection of cavity sites by honey bees may not necessarily include a simultaneous evaluation of food resources. In this study we noted but did not evaluate the survivorship of the individual swarms.

The analysis of landscape structure provides insight into why the pine forest landscape has proven to be suitable habitat for feral honey bees. Six of the seven swarm trap sample units occurred within the study site boundary and analyses were restricted to them. One sample unit occurred on the edge of the study site and was not included in the analyses, as we did not have spatial data for the entire area. Results of the analyses are illustrated in Fig. 6. Although the boundaries of the sample units overlapped in some instances, each provided a different assemblage of landscape elements. Sample unit one is amplified to illustrate the variety of elements that constitute the forest landscape (Fig. 6).

Each of the five indices furnishes different information about the structure of the pine forest, but all indicate that this landscape represents a heterogeneous environment for honey bees. The indices characterize kind, number, size, shape, and configuration of the elements forming the landscape. 
Patch richness, PR (the number of different types of patches, based on the land use/land cover characteristics in Table 1) ranged from 5 to 9 . Three of the patch types are particularly noteworthy from a honey bee habitat perspective: the RCW management areas, the wilderness area, and the private land. The RCW management areas are introduced patches that range in size, but are at least 4.1 ha (Fig. 2). The average for the study site was 74.59 ha (S.D. 55.72 ha). Management practices involve removing midstory vegetation from around woodpecker cavity trees. This activity creates a "park like" opening in the forest matrix, which is an important habitat requirement for the bird (Conner et al., 2001). It also provides sites suitable for the early successional flowering plants which are important sources of nectar and pollen resources for honey bees and other arthropods (Jones, 1993; Rudolph and Ely, 2000). The Little Lake Creek Wilderness Area is vegetated primarily with mixed loblolly/shortleaf pine but also contained a variety of deciduous hardwood species associated with the Little Lake Creek drainage area. These tree species provided both cavity sites and food resources for honey bees. The private property, which included residences with associated outbuildings, was used primarily for cattle and horse ranches. These activities resulted in a perforation of the forest matrix with coastal Bermuda (Cynodon dactylon (L.)) pastureland patches. Again, the presence of human activities introduced both food sources and cavity sites for honey bees.

The number of patches (NP) ranged from 61 to 113. This index is the most straight forward measure of fragmentation. The extensive road and stream corridor network that dissects the landscape contributes to the number of patches observed. We placed a $30 \mathrm{~m}$ buffer on forest road and stream corridors and included them as patches. A $60 \mathrm{~m}$ buffer was placed on highways. The rationale for this approach was that the USDA Forest Service manages roads and streams. The roads typically have an open buffer zone between the surface and the forest edge. The stream corridors, which were intermittent (zero order), are protected by streamside management zones which function to minimize erosion resulting from forestry practices. Both management practices add plant diversity to the pine forest landscape as early successional species are associated with the road corridors and mature hardwood species are associated with the stream corridors.
The patch density, PD (number of patches/ha) ranged from 5.2 to 9.5 and the mean patch size, MPS, from 10.5 to 20.6 ha. Again, both of these indices define a heterogeneous forest environment. The mean shape index, MSI, which ranged from 2.3 to 2.6, reflects the rectilinear structure typical of a managed landscape. The values of this index increase as the shape of the patches become noncircular. As indicated above, the human activities that created fragmentation in the forest landscape also introduced food plants and cavity sites for honey bees.

Our evaluation of structure provides insight into why feral honey bees are an established component of the faunal diversity of the pine forest landscape. The land use classes that characterize the SHNF landscape have different types of vegetation associated with them. Of particular importance to flowering plant diversity were the RCW colony sites, the Little Lake Wilderness Area, private land holdings, and stream and road corridors. Although classified as a pine forest, management practices and human activities have dissected, perforated, and fragmented the landscape. The metrics, used to characterize the kind, number, size, shape, and configuration of elements forming the landscape, define a heterogeneous environment for honey bees that includes food and habitat resources needed for survival, growth, and reproduction. The 1256 ha sample unit size used in this study represents a conservative foraging range for honey bees. Even within the constraints of this sample unit size, considerable landscape structural complexity and vegetation diversity existed. The ensemble of landscape elements that form the study site mosaic is typical of the SHNF at large and representative of the remnant forests throughout the pineywoods ecoregion. Much of the forest land within the ecoregion has been lost to farming, ranching, and urbanization. The study area is a landscape that encompasses the fundamental elements of the ecoregion.

A forest landscape dominated by coniferous tree species would not be expected to support large populations of honey bees, as food resources (both nectar and pollen) are scarce and cavity sites are rare. Indeed, in pine forest landscapes, the RCW is considered to be a keystone species, as it is one of the few organisms that actively initiates and excavates cavities in pines (Conner et al., 1997). Nevertheless, we found feral honey bees to be plentiful in this 
landscape. The persistence of mitotype diversity and the accommodation of newly-immigrated $A$. $m$. scutellata bees suggests that the environment is suitable for honey bee survival, growth, and reproduction.

In highly disturbed forest environments, as the landscapes of the pineywoods ecoregion, it is likely that many of the species- or genera-specific insect pollinators, present at the time of European colonization, have been displaced or destroyed (Buchmann and Nabhan, 1996). Furthermore, the flora of the ecoregion has greatly changed through the introduction of many horticultural plant species. Jones (1993) conducted a comprehensive investigation of the melissopalynology of the ecoregion and this study provides a good indication of the variety of flowering plant species benefiting from pollination services provided by honey bees. Jones (1993) extracted 431 pollen types from honey collected throughout the pineywoods ecoregion, attesting to the role of honey bees as generalists pollinators. The native flora contributed more to east Texas honey than did horticultural taxa. Prominent plant families identified in the study included Rhamanaceae (which contains 55 genera and over 900 entomophilous species), Nyssaceae, Salicaceae, Mimosaceae, Poaceae, and Anacardiaceae. Many of the species included in these families occur within the landscape element types that define the pineywoods ecoregion.

The conclusions that follow from this part of the investigation are as follows: (1) the mosaic of landscape element types that form the SHNF landscape provides sufficient food and habitat resources for honey bees, (2) forestry practices associated specifically with road corridor maintenance, stream side corridor protection, RCW management, and Wilderness Area management introduce structural heterogeneity to the forest landscape which enriches the diversity of early successional flowering plants and provides cavity sites needed by honey bees, (3) ranching, farming, and urbanization also create these conditions, (4) based on inferences from melissopalynology, honey bees provide pollination services for a broad representation of native and introduced flowering plant species of the pineywoods ecoregion.

\section{Acknowledgements}

We acknowledge and thank Mr. Timothy Bigler, Forest Ranger, USDA Forest Service, National Forest
System for facilitating access to the Sam Houston National Forest and for providing the spatial databases used in the study. Ms. Audrey Bunting provided technical assistance in the conduct of the research and in preparation of the manuscript of this paper. Drs. Stephen Buchmann (The Bee Works, LLC and Morpho, Inc.) and Steven Thoenes (BeeMaster, Inc.) provided critical review of the manuscript of this paper. This research was supported by the Texas Legislative Initiative on Honey Bees. M.A. Pinto was supported by the European Union Program PRODEP II (Medida 5/Acção 5.3). K.A. Baum was supported by a Welder Wildlife Foundation Fellowship and the Texas Legislative Initiative on Honey Bees.

\section{References}

Baum, K.A., Rubink, W.L., Coulson, R.N., Bryant Jr., V.G., 2004. Pollen selection by feral honey bees in a coastal prairie landscape. Environ. Entomol. 33, 723-739.

Baum, K.A., 2003. Feral Africanized honey bee ecology in a coastal prairie landscape. Ph.D. Dissertation. Texas A\&M University, $182 \mathrm{pp}$.

Beekman, M., Ratnieks, F.L.W., 2000. Long-range foraging by the honey-bee, Apis mellifera L. Funct. Ecol. 14, 490-496.

Buchmann, S.L., Nabhan, G.P., 1996. The Forgotten Pollinators. Island Press, Washington, DC.

Camazine, S., Visscher, P.K., Finley, J., Vetter, R.S., 1999. Househunting by honey bee swarms: collective decisions and individual behaviors. Insectes Sociaux 46, 348-360.

Clarke, K.E., Rinderer, T., Franck, E.P., Quezada-Euán, J.G., Oldroyd, B.P., 2002. The Africanization of honey bees (Apis mellifera L.) of the Yucatan: a study of a massive hybridization event across time. Evolution 56, 1462-1474.

Conner, R.N., Craig Rudolph, D., Walters, J.R., 2001. The Redcockaded Woodpecker. Univ. TX Press, Austin, TX.

Conner, R.N., Rudolph, D.C., Saenz, D., Schaefer, R.R., 1997. Species using Red-cockaded Woodpecker cavities in eastern Texas. Bull. TX Ornitholo. Soc. 30, 11-16.

Coulson, R.N., Guzman, M.D., Skordinski, K., Fitzgerald, J.W., Conner, R.N., Rudolph, D.C., Oliveria, F.L., Wunneburger, D.F., Pulley, P.E., 1999. Heterogeneity of forest landscapes and the interaction of the southern pine beetle with the Red-cockaded Woodpecker. J. For. 97, 8-13.

Crozier, Y.C., Koulianos, S., Crozier, R.H., 1991. An improved test for Africanized honey bee mitochondrial DNA. Experientia 47, 968-969.

Forman, R.T.T., 1995. Landscape Ecology. Cambridge University Press, Cambridge, UK.

Hall, H.G., Smith, D.R., 1991. Distinguishing African and European honey bee matrilines using amplified mitochondrial DNA. Proc. Natl. Acad. Sci. 88, 4548-4552. 
Hunter, L.A., Jackman, J.A., Sugden, E.A., 1993. Detection records of Africanized honey bees in Texas during 1990, 1991 and 1992. Southwestern Entomol. 18, 79-89.

Jones, G.D., 1993. Melissopalynology of east Texas. Ph.D. Dissertation. Texas A\&M University College Station, TX.

Kerr, W.E., 1967. The history of the introduction of African bees to Brazil. S. African Bee J. 2, 3-5.

Lobo, J.A., Del Lama, M.A., Mestriner, M.A., 1989. Population differentiation and racial admixture in the Africanized honeybee (Apis mellifera L.) Evolution 43, 794-803.

McGarigal, K., Marks, B.J., 1995. FRAGSTATS: spatial pattern analysis program for quantifying landscape structure. Gen. Tech. Rept. PNW-GTR-351. USDA Forest Service Pacific Northwest Res. Stn., Portland, OR, USA.

McGarigal, K.W., Romme, H., Crist, M., Roworth, E., 2001. Cumulative effects of roads and logging on landscape structure in the San Juan Mountains, Colorado, USA. Landscape Ecol. 16, 327-349.

Nielsen, D.I., Ebert, P.R., Page, R.E., Hunt, G.J., Guzmán-Novoa, E., 2000. Improved polymerase chain reaction-based mitochondrial genotype assay for identification of the Africanized honey bee (Hymenoptera: Apidae). Ann. Entomol. Soc. Am. 93, $1-6$.

Pinto, M.A., Johnston, J.S., Rubink, W.L., Coulson, R.N., Patton, J.C., Sheppard, W.S., 2003. Identification of Africanized honey bee (Hymenoptera: Apidae) mitochondrial DNA: validation of a rapid PCR-based assay. Ann. Entomol. Soc. Am. 96, 679684.

Pinto, M.A., Rubink, W.L., Coulson, R.N., Patton, J.C., Johnston, J.S., 2004. Temporal pattern of Africanization in a feral honey bee population for Texas inferred from mitochondrial DNA. Evolution 58, 1047-1055.

Ricketts, T.H., 1999. Ecoregions of North America: a conservation assessment. Island Press, Washington, DC.

Rinderer, T.E., Stelzer, J.A., Oldroyd, B.P., Buco, S.M., Rubink, W.L., 1991. Hybridization between European and Africanized honey bees in neotropical Yucatan Peninsula. Science 253, 309311.

Rubink, W.L., Murray, D., Baum, K.A., Pinto, M.A., 2003. Long term preservation of DNA from honey bees (Apis mellifera) collected in forager traps. Texas J. Sci. 55, 159-168.

Rudolph, D.C., Ely, C.A., 2000. The influence of fire on lepidopterian abundance and community structure in forested habitats of eastern Texas. Texas J. Sci. 52, 127-138.
Schiff, N.M., Sheppard, W.S., 1993. Mitochondrial DNA evidence for the 19th century introduction of African honey bees into the United States. Experientia 49, 530-532.

Schiff, N.M., Sheppard, W.S., Loper, G.M., Shimanuki, H., 1994. Genetic diversity of feral honey bee (Hymenoptera: Apidae) populations in the southern United States. Ann. Entomol. Soc. Am. 87, 842-848.

Schmidt, J.O., Thoenes, S.C., 1987. Swarm traps for survey and control of Africanized honey bees. Bull. Entomol. Soc. Am. 33, $155-158$.

Schmidt, J.O., Thoenes, S.C., Hurley, R., 1989. Swarm traps. Am. Bee J. 129, 468-471.

Schmidt, J.O., Hurley, R., 1995. Selection of nest cavities by Africanized and European honey bees. Apidologie 26, 267-275.

Schneider, S.S., 1989. Spatial foraging patterns of the African honeybee Apis mellifera scutellata. J. Insect Behav. 2, 505-521.

Schneider, S.S., Hall, H.G., 1997. Diet selection and foraging distances of African and European-African hybrid honey bee colonies in Costa Rica. Insectes Sociaux 44, 171-187.

Schneider, S.S., McNally, L.C., 1993. Spatial foraging patterns and colony energy status in the African honey bee Apis mellifera scutellata. J. Insect Behav. 6, 195-210.

Seeley, T.D., Buhrman, S.C., 2001. Nest-site selection in honey bees: How well do swarms implement the "best-of-N" decision rule? Behav. Ecol. Sociobiol. 49, 416-427.

Sheppard, W.S., 1989a. A history of the introduction of honey bee races into the United States Part I. Am. Bee J. 129, 617-619.

Sheppard, W.S., 1989b. A history of the introduction of honey bee races into the United States Part II. Am. Bee J. 129, 664-667.

Sheppard, W.S., Rinderer, T.E., Mazzolli, J.A., Stelzer, J.A., Shimanuki, H., 1991. Geneflow between African- and Europeanderived honey bee populations in Argentina. Nature 349, 782784.

Spicak, M., Fletcher, D.J.C., Breed, M.D. (Eds.), 1991. The “African" Honey Bee. Westview Press, Boulder, CO, USA.

Visscher, P.K., Seeley, T.D., 1982. Foraging strategy of honeybee colonies in a temperate deciduous forest. Ecology 63, 17901801.

Winston, M.L., 1991. The inside story, internal colony dynamics of Africanized bees. In: Spicak, M., Fletcher, D.J.C., Breed, M.D. (Eds.), The "African" Honey Bee. Westview Press, Boulder, CO, USA.

Yaffee, S.L., 1999. Three faces of ecosystem management. Conserv. Biol. 13, 713-725. 